Inclusive Tourism Futures 


\section{THE FUTURE OF TOURISM}

Series Editors: Ian Yeoman, Victoria University of Wellington, New Zealand and Una McMahon-Beattie, Ulster University, Northern Ireland, UK.

Some would say that the only certainties are birth and death; everything else that happens in between is uncertain. Uncertainty stems from risk, a lack of understanding or a lack of familiarity. Whether it is political instability, autonomous transport, hypersonic travel or peak oil, the future of tourism is full of uncertainty but it can be explained or imagined through trend analysis, economic forecasting or scenario planning.

This new book series, The Future of Tourism, sets out to address the challenges and unexplained futures of tourism, events and hospitality. By addressing the big questions of change, examining new theories and frameworks or critical issues pertaining to research or industry, the series will stretch your understanding and generate dialogue about the future. By adopting a multidisciplinary perspective, be it through science fiction or computer-generated equilibrium modelling of tourism economies, the series will explain and structure the future - to help researchers, managers and students understand how futures could occur. The series welcomes proposals on emerging trends and critical issues across the tourism industry and research. All proposals must emphasise the future and be embedded in research.

All books in this series are externally peer-reviewed.

Full details of all the books in this series and of all our other publications can be found on http://www.channelviewpublications.com, or by writing to Channel View Publications, St Nicholas House, 31-34 High Street, BristolBS1 2AW, UK. 
THE FUTURE OF TOURISM: 5

\section{Inclusive Tourism Futures}

\section{Edited by \\ Anu Harju-Myllyaho and Salla Jutila}




\section{Library of Congress Cataloging in Publication Data}

A catalog record for this book is available from the Library of Congress.

Names: Harju-Myllyaho, Anu, 1982- editor. | Jutila, Salla, 1983- editor.

Title: Inclusive Tourism Futures/Edited by Anu Harju-Myllyaho and Salla

Jutila. Description: Bristol, UK ; Blue Ridge Summit, PA : Channel View

Publications, 2021. | Series: The Future of Tourism: 5 | Includes

bibliographical references and index. | Summary: "This book combines

studies of inclusivity in tourism with a future lens and provides timely

insights into current research and discussions on social inclusion. It

considers a future that can be welcoming of different ways of being, doing and knowing to empower all participants in the planning and development of tourism and hospitality"-Provided by publisher.

Identifiers: LCCN 2020056194 (print) | LCCN 2020056195 (ebook) | ISBN

9781845416867 (paperback) | ISBN 9781845416874 (hardback) | ISBN

9781845416881 (pdf) | ISBN 9781845416898 (epub) | ISBN 9781845416904

(kindle edition) Subjects: LCSH: Tourism-Social aspects. | Tourism-Planning. | Social integration. Classification: LCC G156.5.S63 I64 2021 (print) | LCC G156.5.S63 (ebook)

| DDC 338.49104 — dc23 LC record available at https://lccn.loc.gov/2020056194

LC ebook record available at https://lccn.loc.gov/2020056195

\section{British Library Cataloguing in Publication Data}

A catalogue entry for this book is available from the British Library.

ISBN-13: 978-1-84541-687-4 (hbk)

ISBN-13: 978-1-84541-686-7 (pbk)

\section{Channel View Publications}

UK: St Nicholas House, 31-34 High Street, Bristol, BS1 2AW, UK.

USA: NBN, Blue Ridge Summit, PA, USA.

Website: www.channelviewpublications.com

Twitter: Channel_View

Facebook: https://www.facebook.com/channelviewpublications

Blog: www.channelviewpublications.wordpress.com

Copyright (C) 2021 Anu Harju-Myllyaho, Salla Jutila and the authors of individual chapters.

All rights reserved. No part of this work may be reproduced in any form or by any means without permission in writing from the publisher.

The policy of Multilingual Matters/Channel View Publications is to use papers that are natural, renewable and recyclable products, made from wood grown in sustainable forests. In the manufacturing process of our books, and to further support our policy, preference is given to printers that have FSC and PEFC Chain of Custody certification. The FSC and/or PEFC logos will appear on those books where full certification has been granted to the printer concerned.

Typeset by SAN Publishing Services.

Printed and bound in the UK by the CPI Books Group Ltd.

Printed and bound in the US by NBN. 